\title{
In Front of the Mirror of Social Expectations: Experiences of Women Until They Are Given a Diagnosis of Infertility
}

\author{
Katarzyna Walentynowicz-Moryl \\ University of Zielona Góra
}

DOI: http://dx.doi.org/10.18778/1733-8069.16.1.05

Keywords:

primary infertility,

social expectations,

motherhood

\begin{abstract}
The aim of this article is to overview women's experiences in view of social expectations about having children. Such expectations are frequently implied in questions about procreation plans. Since the procreative experience was considered by the author as a process, it was possible to reconstruct changes in the meaning that the researched women ascribed to such questions at different stages of this experience, i.e. from the period prior to trying for a child, through the initial stage of trying to conceive, to the diagnostic stage until being given a diagnosis of infertility. At the stage prior to trying for a child, standing in front of the mirror of social expectations, the women saw themselves in the role of future mothers. At the initial stage of trying to conceive, seeing themselves in the mirror, the interviewed women saw themselves as pregnant women in near future. At the diagnostic stage until being given a diagnosis of infertility, the women saw only their uncertain future, i.e. themselves who wanted to have children very much, but were no longer certain whether they would become mothers.
\end{abstract}

Katarzyna Walentynowicz-Moryl, sociologist and pedagogue, assistant professor at the Institute of Pedagogy at the University of Zielona Góra. Chairwoman of the Zielona Góra Department of the Polish Sociological Association. Scientific and research interests: sociology of health, illness and medicine, non-normative reproductive biographies, qualitative research conducted using the Internet.

\section{Contact details:}

Institute of Pedagogy

Faculty of Pedagogy, Psychology and Sociology

University of Zielona Góra

al. Wojska Polskiego 69

65-762 Zielona Góra

email address: k.walentynowicz-moryl@wpps.uz.zgora.pl 


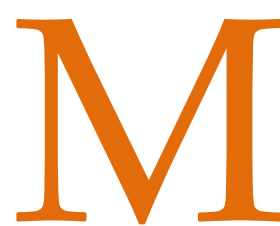

otherhood is one of those experiences that have a dual nature. On the one hand, it is a private, very intimate matter, while on the other hand, "it is also a public phenomenon, a socially defined institution" (Sikorska 2016:137). Due to this fact, the experience is subject to external expectations towards the individual, expressed, among others, through cultural definitions of womanhood. In traditional definitions of womanhood, becoming a mother is treated as an obvious task for a woman; it is her most important life role and a central element defining her as a woman (Dzwonkowska-Godula 2009). Bogusława Budrowska emphasized that despite differences among women, "what unites them is one social expectation, namely, they are all expected to bear children" (2003:57). The researcher has also stated that the imperative of motherhood is deeply rooted in the Polish culture. An adult woman is defined primarily through the obligation to be a mother (Budrowska 2000:14).

However, opinions pointing to changes in attitudes to the meaning of motherhood in a woman's life are becoming more frequent in the literature. Krystyna Slany and Izabela Szczepaniak-Wiecha emphasize that "for the first time ever, contemporary societies have given women the possibility to choose whether they want to procreate - to have or not to have children, women have received a new offer in life - procreative liberty, freedom from the child: (2003:160). Simultaneously, Bogna Bartosz and Katarzyna Bartak point out that women's subjectivity and autonomy are becoming crucial in experiencing motherhood as women "give themselves the right to make subjective choices, including those related to the childless lifestyle" (2011:279). Inga Jaguś speaks in similar terms, stating that "contemporary spouses/ partners can choose: do they want to be parents, or not?" (2015:137)

One can thus ask if contemporary motherhood ceases to be a social expectation directed towards women. Definitely, studies on women that are childless by choice do not fall into the discourse on the permission for the so-called 'procreative liberty' in the Polish society. Researchers indicate that "despite rapid changes undergoing in the contemporary family, people who choose not to have offspring are still stereotypically perceived" (Garncarek 2009:127). Childless women are usually perceived as unhappy, unfulfilled, egoistic, emotionally immature (Gibson and Myers 2000; Przybył 2003). Women themselves declare that their voluntary childlessness is not understood by their social surroundings. Additionally, in the opinion of these women, the same surrounding spressures them to change their decision about being childfree (Garncarek 2009; Cieślińska 2014).

Joanna Tomaszewska indicates that the childless couples that she studied "grew up in the culture of assumed parenthood" (2017:74), which means that the people interested in their procreation did not doubt that the couple would have children. It is emphasized in the literature that most adults automatically take the ability to procreate for granted (Earle and Letherby 2002; van Balen and Inhorn 2002; Danieluk 2005). However, not every procreative biography has the same so-called normative scenario. ${ }^{1}$ Estimates show that the problem of infertility ${ }^{2}$

\footnotetext{
${ }^{1}$ By the normative course of procreative experience, I understand the sequence of quickly occurring consecutive stages: making the decision to have a child - endeavors to conceive - conception - giving birth.

${ }^{2}$ From the medical point of view, infertility is defined as a failure to conceive by a couple after twelve months of regular sexual intercourse without contraception (Janicka, Spaczyński, and Kurzawa 2012).
} 
in Poland may concern between $15-20 \%$ of couples at the childbearing age. According to the most frequent estimates, there are about 1 million infertile couples in Poland (Łukaszuk et al. 2018). Infertility challenges the assumption that parenthood is an inseparable part of adult life. Experiencing infertility raises concerns about the inability to fulfill one's own desires on the one hand and social expectations on the other (Hampshire, Blell and Simpson 2012). In this article, I look into the stories of women whose procreative experience has not taken place in accordance with the normative scenario. These women have been diagnosed with infertility.

It must be emphasized that the literature of the subject devotes most attention to the stage of experiencing infertility connected with the use of advanced reproduction technologies, particularly the in vitro procedure (see, e.g., Holter et al. 2006; Radkowska-Walkowicz 2013). For this reason, I overview the stages preceding this thoroughly described stage of experiencing infertility. In this article, I describe women's experiences regarding social expectations about having children from the moment before they start trying for a child until the moment when they are diagnosed with infertility. I assume that these expectations are expressed in questions about women's procreative plans.

\section{Theoretical Assumptions}

In the literature of the subject, authors frequently point out that there are couples who do not define themselves as infertile despite the fact that they have tried in vain to conceive for longer than a year (see, among others, Jacobson et al. 2017; Johnson et al. 2019). On the other hand, they indicate that some couples, even though they have tried to get pregnant for less than a year, consider themselves to be per- sons who are experiencing difficulties to procreate (see, among others, Dick at al. 2003; Barden-O'Fallon 2005; Marino et al. 2011). Margarete Sandelowski and her team state that the situation of such persons is characterized by the "experience of illness in search of disease" (Sandelowski, Holditch and Harris 1990:199). Therefore, it is being more frequently postulated that infertility should be treated as a socially constructed phenomenon (see, among others, Greil, Slauson-Blevins and Mc Quillan 2010; Johnson and Fledderjohann 2012). It should thus be assumed that "health and illness are best understood, not as objectively measurable states, but as socially constructed categories negotiated by professionals, sufferers, and others within a socio-cultural context" (Greil, McQuillan, and Slauson-Blevins 2011:736).

Within this approach, one distinguishes three ways of understanding malady: as a disease, an illness, and a sickness. Understanding it as a disease draws attention to the medical aspect of the phenomenon. When understood as an illness, on other other hand, it refers to the subjective human experience, which is described by Magdalena Sokołowska (1986) as "feeling ill." However, one should emphasize after Michał Skrzypczak that "an object of interest to a sociologist is [...] not so much a subjective feeling of an individual who is not feeling well, as rather his/her interpretive activity, expressed in ascribing meanings to a malady and to its consequences, as well as activities that are tightly linked to the activities undertaken while it lasts" (2011:345). Finally, understanding malady as a sickness is connected with the social act of labeling an individual as sick.

On the one hand, the above proposed approach to defining health and malady emphasizes subjectivity of an individual, who is able to interpret reality in a reflexive way; on the other hand, it points to the 
fact that individuals invariably experience malady in a socio-cultural context. Thus, the approach falls into the assumptions behind symbolic interactionism. Within symbolic interactionism, I accepted the negotiation-based model of malady (Gerhardt 1989). In this model, individuals are treated as subjects endowed with the right to actively participate in defining the situation in which they find themselves. Every individual who wants to ascribe meaning to a situation, interacts with other subjects and/or contexts, initiating the negotiation process. Every person engaged in the process of negotiation is treated as an individual with specific cognitive constructs. The content of constructs of particular participants in interaction will determine possible scenarios of the negotiation course. An individual who experiences a malady may, but does not have to, accept interpretations of their situation proposed by other negotiating subjects. In the negotiation-based model of malady, it is essential to assume that experiencing it is understood as a process. In order to understand this experience, one needs to take into account also experiences that one had had prior to it.

\section{The Author's Own Study: Methodological Assumptions}

This article is based on selected fragments of empirical material that was collected during the research project titled Procreative Biographies of Women with a Diagnosed Infertility: A Sociological Analysis of the Experience. Given the assumptions of symbolic interactionism adopted here as well as the negotiation-based model of malady, the research was embedded in the interpretive paradigm. The study focused primarily on the interpretative activity of women during their procreative experience - from the stage prior to trying to conceive, through the stages of 'normal procreation' and 'difficult procreation,' to the stage of infertility. The study focused on finding answers to two main questions: (1) What subjects and contexts were important to the interviewed women in constructing the course of their procreative experience? (2) To what extent did the researched women adopt perspectives of those subjects and contexts that they 'wanted' or 'did not want' to involve in their own procreative experience? One of the topics distinguished by the interviewed women as having influence on the course of their procreative experience was people asking about their procreation plans. It needs to be emphasized that the researched women most frequently regarded such persons to be unwelcome and, over time, very often undesired interlocutors. The people asking unwanted questions were precisely those who initiated conversations. In the article, the questions about procreative plans are treated as a way of manifesting social expectations about having children.

When beginning working on that research project, I decided to recruit potential interlocutors on the Internet - specifically through online forums devoted to procreative difficulties. ${ }^{3}$ This decision resulted from the conviction about the necessity to abandon the medical sphere when it comes to research on infertility. ${ }^{4}$ In the study, I used the method of individ-

\footnotetext{
${ }^{3}$ Studies on the use of the Internet by infertile women show that the number of persons who use it as a source of information on infertility is systematically increasing (see, among others, Weissman et al. 2000; Huang et al. 2003; Rawal and Haddad 2005; Talarczyk et al. 2012). In the Polish studies by Joanna Talarczyk and co-workers (2012), 71.5\% of the surveyed patients declared that they used online forums devoted to infertility.

${ }^{4}$ In my studies, I clearly emphasize the necessity for freeing research from the sphere of the medical system. This necessity is not to be understood as negating the importance of a medical space for creating an individual's experience. Rather, it results from the conviction that the medical system is only one of many potential agents that have an influence on how women experience infertility. In the American literature, one can find information that only about a half of infertile women undergo medical treatment (see, e.g., Greil et al. 2010; Adashi and Dean 2016). I did not manage to find data on the percentage of
} 
ual online interviews ${ }^{5}$ (Morgan and Symon 2004; O'Connor, Madge 2008; Bampton, Cowton, and Downs 2013). Within this method, I opted for one of its types, namely asynchronous online interview $^{6}$ (Mecho 2006). In order to conduct the interviews, I interacted with the women via electronic mail (exchange of e-mails) or online forums (exchange of the so-called private messages). During the study, I used interviews based on questions within pertinent thematic areas.

In the course of the study, 81 women diagnosed with infertility shared their stories with me. For the purpose of this article, I selected interviews with 53 of them, specifically those who at that time were experiencing the so-called primary infertility. ${ }^{7}$ These women had never been mothers and had never been pregnant. Therefore, persons asking questions about these women's procreation plans had never

persons who seek medical treatment of infertility in Poland. However, Celina Łepecka-Klusek and her co-workers (Łepecka-Klusek,Pilewska-Kozak, and Jakiel 2012) point out that assisted procreation techniques (APTs, such as insemination or in-vitro fertilization) are used by only $19 \%$ of couples with procreative difficulties.

${ }^{5}$ My experience regarding conducting face-to-face interviews with infertile women showed that direct conversations about infertility with the researched women are difficult for them. They frequently said that they would rather describe their experience in writing. In the case of projects on difficult and personal experiences, indirect contact, including all of its consequences, had a positive impact on the comfort of the interviewed and their willingness to share the experience (Ratislavova and Ratislav 2014).

${ }^{6}$ I opted for the asynchronous online interview method because of its specificity. The difficulty and intimate character of the issue under scrutiny made me feel that it was necessary to attempt to build a trust-based rapport with these women. Such a relationship could develop only during a long-term contact. Additionally, making the interviewed women feel comfortable was absolutely essential to me personally.

${ }^{7}$ Depending on the course of procreative experience, infertility is divided into primary and secondary. Primary infertility refers to those women who had never been pregnant. On the other hand, secondary infertility means that a woman had been pregnant at least once in her life, irrespective of whether the pregnancy ended in giving birth to an alive or a dead child, or, for various reasons, with a miscarriage. had a chance to observe them in the roles of a pregnant woman and/or a mother. As a result, these women's experiences about other people being interested in their procreative situation differ from the experiences of the women who had been pregnant or are mothers. Such differences become particularly conspicuous when their experiences are compared with the experiences of those who have had at least one child.

In this article, by means of comparative analysis (Bohnsack 2001), I attempt to answer the following detailed questions: (1) Have the researched women been asked about their procreation plans? (2) What was the content of these questions? (3) Who asked these types of questions? (4) What meaning did the interviewed ascribe to these messages? (5) How did they react to these types of questions? (6) Did questions about procreation plans have influence on what the researched women thought of their own procreative situation? Since procreative experience is considered here to be a process, I took a closer look at the following three stages in the women's procreative experience: (1) the stage prior to trying to conceive, (2) the initial stage of trying to get pregnant, (3) the diagnostic stage until being given a diagnosis of infertility.

\section{The Characteristics of the Researched Women}

The protagonists of this article are a heterogenous group when it comes to their socio-demographic characteristics and the course of procreative experience. The youngest woman was 23, while the oldest one was 44 years old. The largest category included women between 26 and 30 years old. Only three women were above 40. Almost every researched woman has been married for 2-5 years. 
The biggest group of women lived in cities with more than 100 thousand inhabitants. A vast majority of my interlocutors were well-educated (higher education). Two had doctoral degrees. At the time of the research, the majority of the researched women were employed; only some of them stayed at home or studied. Regarding the characteristics of the course of their procreative experience, the women varied when it comes to the moment at which their approach to the prior course of trying to conceive started to change. Most frequently, they started worrying about their procreative situation after about half a year of failed trying; most rarely, after a year. In most cases, the change in the attitude to their own situation resulted in consultations with the gynecologist. The researched women were given an infertility diagnosis about 1.5 years after they had first started trying to get pregnant.

\section{The Manifestation of Social Expectations: Questions About Procreative Plans}

The interviewed women were asked whether they have even been in a situation when they were asked about their procreation plans. Each of the 53 women answered affirmatively. It needs to be emphasized that in their answers, the researched women used the following terms: 'obviously,' 'certainly,' and 'sure.' Their answers included fragments indicating that such experiences were common: "After all, every young woman goes through that" (W819), "I do not know a girl who has not been asked that" (W38). In the opinion of the interviewed, having a child is a socially expected element of a women's biography - "It just is so that everyone thinks that a child is going to appear at some point" (W13), "Sooner or

${ }^{8 `} \mathrm{~W}^{\prime}$ stands for woman. All the quotes have been translated from Polish into English by myself. later someone is going to state that the only thing missing from this woman's life is a child." The researched women felt that people asking about their procreative intentions considered this to be as good as any other conversation topic - "Questions about work, holidays, when we are going to have kids, what difference does it make?" (W33), "Afterall, you can ask about everything, can't you? To those people, it is also a normal topic"(W52).

The interviewed women emphasized that in the situation when someone was interested in their procreative intentions, most frequently the person began their questions with the adverb 'when,' e.g. 'When are you going to have a child?' 'When are you going to be a mother?' 'When is your family going to get bigger?' 'When are you two going to begin trying?' And, 'when is your turn?' The interviewed women stated that the questions asked had rarely been: 'Are you/you two planning to have a child?' For the majority of the inquisitivepeople, it was not important whether the interviewed women thought about having a child at all, but at what point they would take on the role of a mother. The need to have a child was regarded by the majority of the interlocutors as an obvious thing "It was obvious to everyone that we were going to have a child" (W4), "To them, such questions were a normal thing, afterall, 'everyone wants to have kids'” (W37). Such thinking was particularly frequent when a woman was married: "It seemed normal to everyone that since there had been a wedding, people had the right to ask about whether we were planning a child" (W50). In the opinion of the researched women, being married was coupled with an increase in the number of questions about plans to have children - "After the wedding, it all really started, the topic was being constantly brought up" (W14). Part of the interviewed wom- 
en pointed to the apparently popular concept of the so-called 'right age' to have children - "They thought that it was simply a good time, and I was at that age, for a woman, to have children" (W27), "They came to the conclusion that I was grown-up enough to think about the future and could, finally, have those kids" (W45).

When analyzing the statements from the researched women, one must say that the topic of having children was invariably initiated by persons asking them about procreation plans. In the case of my interlocutors, those people described a couple's situation as good to have children. The fact that a woman had no child in such a situation was regarded as incompatible with the content of these persons' cognitive constructs. When asked about who made questions about their procreation plans, the interviewed women indicated representatives of the following three groups: family members, friends, acquaintances. Almost every woman stated that family members asked about their plans to have kids, but the women were not specific about who that was. Once they shared that information, they most frequently enumerated parents and parents-in-law. It is worth emphasizing that the women frequently pointed to the members of the so-called extended family, namely grandmothers, grandfathers, aunts, uncles, and cousins. Acquaintances were alsomentioned in this context. One should notice that the interviewed women recognized that their friends asked about their procreation plans to a lesser extent. Importantly, the set of the persons asking was changing together with subsequent stages of the women's procreative experience. This was particularly due to the fact that over time the majority of the researched women decided to inform selected persons about trying to get pregnant.
In the further part of the interview, I asked the women about what meaning they ascribed to questions about their procreation plans. Next, I asked them about whether the emergence of such questions had any influence on what they thought of their procreative situation. Every woman admitted that along with subsequent stages of their procreative experience their attitude to such questions was changing - "Well, it depends on what time we are talking here about" (W13), "I noticed that with every next cycle the same questions started to sound different" (W27).

The next consecutive sections of this article are devoted to the three stages in the procreative experience of the researched women: (1) the stage prior to trying to conceive, (2) the initial stage of trying to get pregnant, (3) the diagnostic stage until the moment of being diagnosed with infertility.

\section{The Stage Prior to Trying to Conceive}

The interviewed women can be divided into two categories in terms of meaning that they ascribed to the questions about their plans to have children at the stage prior to trying to conceive: 1) 'procreative questions - appropriate questions,' 2) 'procreative questions - inappropriate questions.' To the researched women from the first distinguished group, questions about their procreative intentions were simply one of conversation topics with other people. Speaking about this type of questions, the women used such terms as: 'normal' - "Then, I treated these questions as something normal" (W26), "These were normal questions, just like any other questions" (W52); 'obvious' - "Afterall, obvious questions, the ones you could expect" (W14), "It seemed obvious that finally someone would start asking about this" (W34); 'natural' - "At that time, I considered these 
to be natural questions" (W19), "Somehow, at that time, conversations on this topic seemed so natural to me" (W31). These women coupled the emergence of questions about procreation plans with their own life situation. They pointed to the following elements of this situation: getting married - "We were married, no wonder that such questions emerged" (W22), "There had been a wedding and now it was time for children, it was so obvious to everyone" (W25), or wedding planning - "A normal question to a woman who is planning her wedding" (W8), "Once we had started wedding preparations, such questions became normal" (W33), and age - "These were normal questions, adequate to our age" (W29), "I reached the age at which questions about children were nothing unusual" (W51). Given such an attitude, this type of questions did not evoke any emotions in the interviewed women - "I approached these questions in a normal way, without any particular concern" (W37), "At that time, it never occurred to me to worry about this" (W42).

On the other hand, at the stage prior to trying to conceive, the women from the latter distinguished category considered questions about their procreation plans to be 'inappropriate' - "I did not understand why people asked me such questions, it was, at least, inappropriate" (W11), "I thought that such questions should not be asked, people should not be interested in when I was going to start a family" (W49), In the opinion of these women, the topic of procreation plans was their private matter - "It was my private matter" (W15), "I did not think that such private matters should be of interest to anyone" (W38). These women regarded questions about procreation plans as an interference in the intimate sphere of their lives - "Why should I let anyone into such an intimate part of my life?" (W2), "What did they care about whether I wanted to have a child, or when I wanted to have one. These were very intimate questions" (W19). Such an approach caused that questions about procreation plans evoked very strong emotions in the researched women - "When I heard something like this, I immediately got irritated" (W24), "I got angry at the persons who thought they had the right to ask me about when I would finally have that child" (W46).

Whether questions about procreative plans had any influence on the way the researched women thought depended - at the discussed stage of their experience - on how they approached motherhood. Prior to starting their endeavors to conceive, all the interviewed women had been convinced that motherhood would be one of those obvious experiences that would take place in their lives: "It was obvious to me that I would have children" (W22). "Having children was a taken for granted stage in my life" (W43). Plans of the researched women varied, however, when it comes to details about taking on the role of mothers. Given this criterion, one can distinguish between two categories of women: 1) 'women with a conditional approach to motherhood,' 2) 'women who approach motherhood in an unconditional way'.

The researched women from the first category had a very detailed plan determining what their life situation should look like so that they could decide to have a child" - "I wanted to have children once I had everything ordered" (W24), "According to the plan, a child was to appear in our life once we had passed through the earlier stages" (W47). What accompanied those women was a strong conviction that

\footnotetext{
${ }^{9}$ Before becoming mothers, these women first wanted to tick off a few other points from the prepared list: graduate from university, find the right partner, get married, achieve a stable financial situation, and find own apartment.
} 
they must concentrate on the assumed action plan. Thus, at this stage of their experience, questions about their procreation plans did not have any influence on what they thought of their own situation - "I knew then what I wanted, and the questions did not change anything" (W32). "The fact that someone asked me when a child would appear did not lead to any reflections. I had it all planned then" (W38). The women from this category emphasized that it was themselves who decided about what course their procreative experience would take - "They could ask me, but, afterall, I was the one who decided about it" (W1), "It was my individual decision, and what my aunt, uncle, grandmother said hadno influence on my decision" (W19). The women in this group considered questions about having children as 'appropriate questions' and had no problem with answering them, informing about their assumed agenda - "I answered in accordance with our plan, that one thing would follow another: first job, flat, then a child" (W16), "We used to say that I would first graduate from uni, only then get a job and have a child" (W36). On the other hand, the women who considered the questions to be 'inappropriate' tried to avoid answering them - "I pretended not to have heard the question and to change the topic" (W3), "Instead of answering, I asked the same question or came up with a different one" (W27).

In contrast, the women with the unconditional approach to motherhood did not plan the moment at which they wanted to become mothers - "I have always wanted to have children, but I have never thought about what the best time to have them would be" (W7), "I wasn't planning anything. I knew that I would be a mummy one day, and I dreamt of being pregnant" (W33). To these researched women, taking on the role of mothers in the future was related only and exclusively to the emergence of the wish to become mothers - "I was convinced that the moment would come and I would want to finally be a mother, then I would not be looking back to anything" (W29), "At that time, it seemed so natural to me that at some moment one wants to have a child" (W50). In the case of the women in this category, questions asked about their procreation plans resulted in them starting to think more frequently about trying to conceive - "More and more people were asking, and I was increasingly thinking that maybe it was that time" (W6), "I finally wanted to become a mother, so I started thinking more seriously about it" (W45). Part of these women emphasized that conversations about their procreation intentions encouraged them to try to conceive - "I imagined then that it would be nice to have a child already" (W15), "Somehow, after such conversations, I was more convinced" (W31). Every woman in this category thought that questions about their procreation plans were 'appropriate.' Given this, at the analyzed stage of their experience, the interviewed women were more willing to share the information that they were planning to have a child in the future. However, they were not precise about the moment at which they wanted to take on the role of mothers - "Then, I kept saying that I wanted to have a child" (W27), "I used to answer that everything had its time, and a child would definitely appear in our family" (W40).

\section{The Initial Stage of Trying to Conceive}

At the initial stage of trying for a baby, the researched women approached the questions about their procreation plans in the same way as they had approached them at the prior stage. Although their procreative situation changed, they still fell into the group of those who considered these questions to be either 'appropriate' or 'inappropriate'. However, asking such questions at the point when they had 
already started trying evoked completely different emotions in them. One must emphasize that all the interviewed women were convinced that they would manage to get pregnant and give birth to a child: "I deeply believed that we would get pregnant without problems" (W35), "I believed then that we would succeed" (W48). None of them thought then that they could not succeed -“Don't even think that something might go wrong" (W43), "The scenario titled 'we will not be able to' was not even plausible to me then, it would not have come to my head then" (W50). Given this, questions concerning procreative plans resulted in the women's thoughts oscillating around being pregnant - "These questions caused that I frequently imagined what it would be like when I finally am pregnant" (W6). "I kept thinking solely that I would soon be pregnant and I would start getting ready for my child's arrival" (W20). This made the interviewed women experience only positive emotions - "I already wanted a child so much that I was happy with these questions" (W48), "At that time, I was excited with every such question" (W35). Such feelings emerged as a reaction to questions about procreative intentions also in the case of these women who considered them to be 'inappropriate questions' - "On the one hand, I was angry; on the other hand, I couldn't prevent myself from smiling" (W24) "I was crazy happy then, even though I still thought it was our private matter" (W39).

In relation to questions about procreative plans, the majority of the interviewed women did not decide to share the information about trying to conceive with other people. The interviewed women considered these questions to be 'inappropriate' and they pointed out that they thought so because they were convinced they would quickly get pregnant: "I concluded that there was no reason to boast of our try- ing for a child, and I would rather quickly boast of my pregnancy" (W8). "We did not tell anyone. We thought it would be a matter of a few months, and then we would give the happy news to everyone" (W25). Secondly, the interviewed women did not reveal the information about trying for a child precisely because they wanted to surprise their closest ones: "My mother was waiting for a grandchild, I wanted her to be surprised because she thought we still did not want a child"(W2), "We waited long to have a child, and we wanted to surprise our family" (W49). At that stage, the researched women still answered the questions, but the content of their answers changed. They no longer explained when, in their opinion, the right moment to have a child would come, nor did they ensure the interlocutor that they wanted to take on the role of mothers. They started giving evasive answers, such as - "I told you there would be time for everything" (W10), "I was giving vague answers, like, 'we still have time"' (W27). On the other hand, the women who considered questions about their procreation plans to be 'inappropriate,' once more emphasized that this sphere of life was their private matter - "I did not think that I should share our private matters with others" (W11), "I didn't use to share my private matters with anyone" (W35). However, they still tried to avoid giving answers to questions about their procreation plans.

Some of the interviewed women decided to share the information about trying to conceive with selected persons, most frequently members of their own family (mother or parents and/or their husband's/ partner's parents) and friends. When asked about the reasons for such a decision, the women most frequently pointed out that to them it was a natural behavior: "Afterall, it is natural that you share with others the news about what is going on in your life" 
(W7), "It was so natural to me, normal to tell them about it" (W40). What made this behavior seem so natural to these women was primarily the character of relations between them and these persons: "We have always been close, we tell one another what important is happening in our lives" (W28), "I told my family, we have always tried to be 'up-to-date' about one another's lives" (W46). Another reason why the researched women decided to inform somebody about trying for a child was the need to share the happiness resulting from this fact: "We were so happy, I wanted everyone to learn about this" (W29), "I was so happy then that we were finally trying to get pregnant" (W30). The people who were informed about the fact that the women began trying to conceive stopped asking questions about procreation plans and became interested in the course of these endeavors - "We were asked how our trying was going and when we would be breaking the happy news" (W11), "The persons who knew became interested in our progress" (W23). In the initial period of trying to conceive, these women who shared with others the information about trying for a child reacted positively to other persons' interest - "I was happy that they kept asking about our progress; afterall, I was sure that in our next conversation I would break the happy news" (W28), "It was nice, afterall, conversations about trying were soon to turn into those about my pregnancy" (W44).

Analyzing the initial stage of trying to conceive, one needs to notice that at some point ${ }^{10}$ the researched women started noticing that despite having tried for some time now, they still were not pregnant: "At some point, it occurred to me that I still wasn't pregnant" (W11), "Another month behind us, and

\footnotetext{
${ }^{10}$ I.e. after a few months, after half a year, or after a year of procreative activities.
}

still no sign of pregnancy" (W40). For the first time, the women started thinking about their procreative situation: "It was the first time when I started thinking about what was happening" (W3), "I wondered what I should think of this all" (W39). In their statements, the researched women emphasized that they had assumed that they would quickly succeed and get pregnant without problems: "Pregnancy was to come quickly and without problems" (W8), "I did not understand, I was sure that the tricky bit was not to get pregnant" (W11). The interviewed women were faced with the necessity to confront their expectations about the course of their procreative experience with the facts about its course: "I started thinking about how I had imagined our trying for a child and what the reality was" (W32), "Then, I took the stock of how it was supposed to have been and how it really was" (W35). The researched women started talking about the lack of pregnancy, using terms such as: 'some problem,' 'something is not ok, 'something is happening,' 'something is not right.' Such a way of thinking resulted in the women starting to feel anxious: "I began worrying seriously" (W10), "Since that moment, I worried even more" (W24). Part of the women said directly that they began worrying: "Since that moment, I worried more frequently that something was wrong" (W48), "I started worrying that something was not right" (W50).

A change in the perception of their own procreative situation made the women's approach to having children gradually change. It is particularly visible in the case of those interviewed women who at the stage of trying to conceive considered such questions to be 'appropriate questions' -"At some point, the questions that I had regarded as normal started bothering me" (W13), "I still think that there is nothing wrong with these questions, but I no longer 
smiled when I heard them" (W33). The researched women declared that after their approach to their own procreative situation had changed, they started reacting badly to questions about their procreation plans -"Once I started thinking that we had a problem, I more frequently felt bad when someone asked about a child" (W10), "At that point, I started taking every such question emotionally"(W39). These questions made the interviewed women face their own doubts and fears. In the case of some of the researched women, such questions fueled their fears - "Another unsuccessful cycle and someone was again asking me when I would have a child, it was difficult to fight fear" (W3), "I wanted to say that I was pregnant, but I still couldn't. This simply worried me even more" (W27). On the other hand, in some of the women the questions about procreation plans intensified the frustration caused by the inability to fulfill their goal - "Those questions made it even more difficult for me to endure subsequent failures to get pregnant" (W9), "I felt then even more disappointed that we couldn't succeed" (W43).

\section{The Diagnostic Stage Until the Moment of Being Given the Diagnosis}

At the diagnostic stage until being given a diagnosis of infertility, the meaning ascribed by the women to questions about their procreation plans changed significantly. Those researched women who at the previously discussed stages of their procreative plans had considered such questions to be 'appropriate,' changed their opinion now. For the majority of them, what became inappropriate was not the fact itself that such questions were asked, but the frequency with which they were asked, and/or their content. The women had an impression that questions about their intentions to have children were asked more frequently than in the past - "I had an impression that everyone kept asking about it. I think it had not been like this earlier" (W29), "As long as these were just a few questions within a long space of time, it was ok. However, they were now asked very frequently and, in addition, as the first question" (W44). Only at this stage, the answers of the researched women contained phrases indicating that they began feeling pressure in relation to their procreation plans - "Those were no longer normal questions. Hearing them, I felt that I must finally get pregnant" (W27), "Wherever I went, always the same topic, I felt under pressure" (W41).

Some of the women pointed out that the questions came together with unpleasant comments and remarks. Most frequently, in such statements, people suggested that the researched women did not want to have children at all - "I kept hearing that I did not want a child at all" (W5), "Stupid texts that we surely weren't planning to have children" (W36). In the opinion of the interviewed women, this type of comments resulted from the fact that the inquisitive people thought that the women should already have a baby - "You have been married for so many years, and still no signs of a child" (W29), "I heard this over and over again - how much longer are you going to wait, your situation is not going to get better" (W51). The persons who made such comments in front of the researched women frequently assessed their motivation negatively - "People frequently used phrases like 'egoists, you are more comfortable without children, you simply want stay in bed all day long"” (W25), “What are we waiting for? Do we want to make more money instead of having children?" (W49). Some of these women faced allusions that questioned the procreative abilities of their husbands/partners - "Once, my cousin stated that 'you can't have children because your M. is shoot- 
ing blanks'” (W32), "Some vulgar statements appeared, something like that $\mathrm{M}$. is shooting blanks, and things like that" (W37). Occasionally, the interviewed women faced vulgar proposals to help in trying for a child - "We frequently heard jibes like: 'maybe you need help, after so many years, you have still not learned how to do it; you two must have separate bedrooms, what are you waiting for?'" (W 34), "'Well then, what about that child, maybe I should help you?'"' (W41).

The experience of being given a diagnosis of infertility made the researched women change the attitude to their prospective motherhood. The reality in which they found themselves forced them to question their earlier convictions about the obviousness of having children and the conviction that it would become their experience, too - "I got a strong blow from the fate, I had been convinced that everything would work, now I no longer was" (W15), "I had to face the truth, there was nothing left of my conviction that I would be holding my child" (W52). Insecurity started accompanying the researched women - "That constant insecurity whether we will finally succeed and I will become a mother" (W30), "Insecurity, that feeling, that never left me" (W44). In light of this, the situations when the interviewed were asked about their procreation plans were more difficult to deal with. Such types of questions resulted in the women not being able to stop thinking about the situation in which they were even for a while - "Even when I tried not to think about this, one question was sufficient, one comment and it all started again. They could have as well hung a banner that says: 'Remember, something is wrong with you"' (W1), "They kept reminding me that we were not able to get pregnant" (W49). The necessity to confront such questions made the women even more affected by what they were going through - "It was difficult enough, and such situations only made me feel worse" (W12), "After every such conversation I couldn't come to grips for a long time, it was only worse" (W32). Additionally, in some of the researched women, the confrontation intensified the anxiety about whether they would manage to fulfill the expectations directed at them - "I was thinking about what would happen if we can't succeed" (W15), "I wanted to become a mother so much, and I was increasingly afraid that I might not experience motherhood" (W15). Over time, the majority of the researched women began to purposefully avoid situations in which someone could ask them about their procreation plans - "For some time now, I have avoided meeting other people like fire, I haven't visited my aunts, uncles, etc. so that I don't have to explain why we still haven't got children" (W15).

Given all the questions about their procreation plans, in the beginning of experiencing infertility, the majority of the researched women decided not to share this information with the inquisitive people. The interviewed emphasized that it was a challenge for them to admit that they had trouble conceiving - "I would have had to admit that we weren't able to conceive, and this was difficult to me" (W6), "Simply, I myself felt bad about this situation and I didn't want anyone to know" (W19). Some of the researched women justified this with their hope that thanks to the treatment they would quickly get pregnant - "I didn't want to talk about this, I hoped that we would manage to quickly solve the problem with a doctor's help"(W3), "I believed that I would soon be able to say that I am pregnant" (W36). Like in the case of informing about starting trying to conceive, some of the researched women still thought that the course of their procreative experience was their private matter - "I didn't want to tell anyone because I still considered this to be a too 
intimate matter" (W24), “Our problems are only our business" (W34). The interviewed who initially had decided not to share the information about their infertility problem with the persons asking about their procreation plans now adopted two strategies of answering such questions. The first one consisted in giving very general answers, such as - "As soon as I am pregnant, you will immediately know" (W22), "Time will show when we will have a child" (W36). The second strategy was to avoid answering such questions - "I tried to change the topic so that I didn't have to answer" (W25), "I usually immediately put an end to the topic" (W51).

Over time, some of the women who initially had not informed anyone about their infertility decided to share this information with some people precisely due to constant questions about their procreation plans - "I was fed up with those constant, stupid questions. It was clear now: we want, but we can't" (W10), "At some point, I was already fed up, I'd rather they did not know that we are undergoing treatment so that they don't keep asking when we would have a child" (W36). However, some of the interviewed women still decided not to inform anyone about their infertility. Some of them concluded that they would start answering questions in such a way so that no one wants to ask them anymore "Later, being fed up with such questions, I started to answer with other questions - 'is your wife happy with your sex life?' 'How much do you earn?' 'How often do you sleep with your husband?' After that, they left me alone" (W41). "I started to react aggressively, I attacked immediately and I tried to hit their sensitive points, e.g. being overweight after pregnancy, their material situation" (W49). Some of the women preferred being treated as childless by choice to being treated as infertile - "I eventually started to say that we did not want a child. It was easier than admitting infertility" (W19), "I changed by approach. If others thought I did not want to become a mother, so let it be so" (W18).

The majority of those researched women who decided to inform some people about trying to conceive, also decided to inform them about the fact that they were facing the problem of infertility. To some of them, this was a natural decision resulting from the need to get support from their closest ones in such a difficult situation - "I told them, because these were people close to me and I expected help, support, listeners" (W6), "I think I was simply sad and wanted them to worry (together) with me" (W15). However, some of the women decided to take this step only because they could no longer handle other people's interest in the effects of their trying - "I was fed up with them analyzing whether I was pregnant just because I was not drinking wine or was wearing a shift" (W3), "How many times can you listen to the question 'has it finally happened'?" (W45).

\section{Concluding Remarks}

The analysis of the stories that the interviewed women shared with me indicates that being asked about procreation plans is common. The fact that such questions emerge is inextricably linked with the widespread traditional convictions held by the Polish society about motherhood. Frequently, the questions directly express the assumption that motherhood is an obvious experience in every woman's life. The basic question should not be 'whether a woman is planning to have children,' but 'when she is planning to have children,' Reactions of infertile women to this matter are similar to those presented in studies on women who are childless by choice. Research unequivocally testifies to the fact 
that women in Poland still live in the so-called 'culture of assumed parenthood' (Tomaszewska 2017). In this culture, asking questions about procreative intentions is considered to be an ordinary element of interaction particularly with married women and with those women who, according to social norms, are at the 'right age' to have children. In the literature of the subject, the relationship between getting married and procreative expectations is particularly emphasized (Budrowska 2000; Cieślińska 2014).

How the researched women approached motherhood turned out to be particularly important in relation to the meaning ascribed by them to questions about their procreative plans, and to how these questions related to what they thought of their own procreative situation. Framing the procreative experience of the women diagnosed with primary infertility as a process allowed me to overview changes that occurred in the course of their experience: from considering motherhood as a normative life event - which, as the researched women believed at the stage prior to trying for a child, would be part of their lives - and the initial stage of trying to conceive, through doubts and fears connected with the actual course of their endeavors at the final stage of trying for a child, to the anxiety about whether they would experience motherhood at the diagnostic stage and, finally, to the stage of receiving a diagnosis of infertility. Together with changes in the women's approach to their own motherhood, their perception of questions about their procreative plans changed as well.

At the initial stage, the majority of the interviewed women considered questions about their procreative plans to be an obvious, normal and natural element of interaction with other persons, evoking no emotions. The women considered such questions to be 'appropriate questions'. Social expectations implied in the questions coincided with these women's own expectations, which they initially planned to fulfill in the near future, and next when they started trying to conceive. However, already towards the end of the initial stage of trying to conceive, the researched women's attitude to such questions started changing. The questions evoked doubts and anxiety in them. At the stage of being diagnosed until the moment of being given the diagnosis, the majority of the interviewed women no longer considered such questions to be 'appropriate.' The emergence of such questions in interactions with others made it more difficult for the women to handle the situation in which they were. Such questions forced the interviewed women to confront the insecurity about whether they would be able to fulfill their desire to become mothers on the one hand and social expectations on the other. The questions expressed social expectations which these women might not be able to meet.

The researched women standing in front of the mirror of social expectations at the stage prior to trying to conceive saw their future in this, i.e. themselves in the role of mothers. In the case of those interviewed women who had a very precise agenda as to when they would take on the role of mothers in their lives, other persons' interest in their procreative experience had no influence on their procreative decisions. They emphasized their subjectivity and autonomy. On the other hand, the women without any precise plans to become mothers perceived questions about procreation plans as an encouragement to begin procreative activities. At the initial stage of trying for a child, looking into the mirror of social expectations, the researched women saw in their near future themselves as pregnant women. Questions about their 
procreative plans were a nice experience for them, which additionally confirmed for them that they wanted to be mothers. However, when the interviewed women started noticing that their assumed course of procreative experience was not happening, they saw in that mirror their own anxiety and fears. At the diagnostic stage until the moment of

\section{References}

Adashi, Eli Y. and Laura A. Dean. 2016. “Access to and use of infertility services in the United States: framing the challenges." Fertility and Sterility 105(5):1113-1118.

Bampton, Roberta, Christopher Cowton, and Yvonne Downs. 2013. “The E-Interview in Qualitative Research." Pp. 329-343 in Advancing Research Methods with New Technologies, edited by N. Sappleton. Portland: International Science Reference.

Barden-O'Fallon, Janine. 2005. “Associates of self-reported fertility status and infertility treatment-seeking in a rural district of Malawi." Human Reproduction 20(8):2229-2236.

Bartosz, Bogna and Katarzyna Bartak. 2011. "Zamierzona bezdzietność wyborem autobiograficznym współczesnych kobiet." Pp. 275-300 in Wymiary kobiecości i męskości: Od psychobiologii do kultury, edited by B. Bartosz. Warsaw: Wydawnictwo Eneteia.

Bohnsack, Ralf. 2001. “Dokumentująca interpretacja wzorów orientacji działania." Pp. 170-189 in Jakościowe orientacje w badaniach pedagogicznych: studia i materiały, edited by D. Urbaniak-Zając and J. Piekarski. Lodz: Wydawnictwo Uniwersytetu Łódzkiego.

Budrowska, Barbara. 2000. Macierzyństwo jako punkt zwrotny $w \dot{z}$ yciu kobiety. Wroclaw: Fundacja Na Recz Nauki Polskiej.

Budrowska, Barbara. 2003. "Znikoma reprezentacja kobiet w elitach - próby wyjaśnień." Pp. 39-67 in Szklany sufit. Bariery i ograniczenia karier kobiet. Monografia zjawiska, edited by A. Titkow. Warsaw: ISP.

Cieślińska, Barbara. 2014. "Bezdzietność jako styl życia." Pogranicze. Studia Społeczne 24:277-292. receiving a diagnosis of infertility, the women saw in the mirror only their own insecurity, i.e. themselves who wanted to be mothers very much, but where no longer certain whether they would succeed and have children eventually.

Daniluk, Judith C. 2005. "Reconstructing their lives: a longitudinal, qualitative analysis of the transition to biological childlessness for infertile couples." Journal of Counseling E Development 79(4):439-449.

Dick, M-L. B. et al. 2003. "Self-reported difficulty in conceiving as a measure of infertility." Human Reproduction 18(12):2711-2717.

Dzwonkowska-Godula, Krystyna. 2009. “Macierzyństwo i ojcostwo jako nowe doświadczenie kobiety i mężczyzny." Acta Universitatis Lodziensis. Folia Sociologica 34:107-125.

Earle, Sarah and Gayle Letherby. 2002. "Whose choice is it anyway? Decision making, control and conception." Human Fertility 5(2):39-41.

Garncarek, Emilia. 2009. “Kobieta bez dziecka vs. mężczyzna bez dziecka w świetle wypowiedzi autorów postów internetowych." Acta Universitatis Lodziensis Folia Sociologica 34:127-140.

Gerhardt, Utha. 1989. Ideas about Illness. An Intellectual and Political History of Medical Sociology. New York: New York University Press.

Gibson, Donna M. and Jane E. Myers. 2000. “Gender and Infertility: A Relational Approach to Counseling Women." Journal of Counseling \& Development 78:400-410.

Greil, Arthur L., Julia McQuillan, and Kathleen Slauson-Blevins. 2011. "The social construction of infertility." Sociology Compass 5(5):736-746.

Greil, Arthur L., Kathleen Slauson-Blevins, and Julia McQuillan. 2010. "The experience of infertility: a review of recent literature." Sociology of Health \& Illness 32(1):140-162. 
Hampshire, Katherine R., Mwenza T. Blell, and Bob Simpson. 2012. "'Everybody is moving on': Infertility, relationality and the aesthetics of family among British-Pakistani Muslims." Social Science \& Medicine 74(7):1045-1052.

Holter, H.et al. 2006. "First IVF treatment - short-term impact on psychological well-being and the marital relationship." Human Reproduction 21(12):3295-3302.

Huang, J. Y. J. et al. 2003. "Internet use by patients seeking infertility treatment." International Journal of Gynecology $\mathcal{E}$ Obstetrics $83(1): 75-76$.

Jacobson, Melanie H. et al. 2018. "Research on Infertility: Definition Makes a Difference" Revisited." American Journal of Epidemiology 187(2):337-346.

Jaguś, Inga. 2005. “Od wielodzietności do bezdzietności? Przemiany w poglądach na posiadanie dzieci i ich uwarunkowania." Roczniki Socjologii Rodziny 16:127-139.

Janicka, Anna, Robert Z. Spaczyński, and Rafał Kurzawa. 2015. "Assisted reproductive medicine in Poland - Fertility and Sterility Special Interest Group of the Polish Gynaecological Society (SPiNPTG) 2012 report." Ginekologia Polska 86(12):932-393.

Johnson, Katherine M. and Jasmine Fledderjohann. 2012. “Revisiting 'her' infertility: Medicalized embodiment, self-identification and distress." Social Science E Medicine 75(5):883-891.

Johnson, Katherine M. et al. 2019. “Infertility and Self-identification: The Indeterminacy of the Illness-self Relationship." Sociological Perspectives, p. 1-18. Retrieved November 12, 2019 (https:// journals.sagepub.com/doi/abs/10.1177/0731121419867691?journalCode $=$ spxb).

Łepecka-Klusek, Celina, Anna B. Pilewska-Kozak, and Grzegorz Jakiel. 2012. “Niepłodność w świetle definicji choroby podanej przez WHO." Medycyna Ogólna i Nauki o Zdrowiu 18(2):163-166.

Łukaszuk, Krzysztof et al. 2018. “Diagnostyka i leczenie niepłodności - rekomendacje Polskiego Towarzystwa Medycyny Rozrodu i Embriologii (PTMRiE) oraz Polskiego Towarzystwa Ginekologów i Położników (PTGP)." Ginekologia i Perinatologia Praktyczna 3(2):112-140.

Marino, Jennifer L. et al. 2011. "Fertility treatments and the young women who use them: an Australian cohort study." $\mathrm{Hu}$ man Reproduction 26(2):473-479.
Meho, Lockman I. 2006. “E-Mail Interviewing in Qualitative Research: A Methodological Discussion." Journal of American Society for information Science and Technology 57:1284-1295.

Morgan, Stephanie J. and Gillian Symon. 2004. “Electronic interviews in organizational research." Pp. 23-33 in Essential Guide to Qualitative Methods in Organizational Research, edited by C. Cassel and G. Symon. London, Thousand Oaks, New Delhi: Sage Publications.

O'Connor, Henrietta and Clare Madge. 2008. “Online Interviewing." Pp. 271-288 in The SAGE Handbook of Online Research Methods, edited by N. Fielding, R. M. Lee, and G. Blank. Los Angeles, London, New Delhi, Singapore: Sage Publications.

Przybył, Iwona. 2003. “Naznaczanie społeczne i samonaznaczanie osób niepłodnych." Blaski i cienie życia rodzinnego. Roczniki Socjologii Rodziny 15:47-61.

Radkowska-Walkowicz, Magdalena. 2013. Doświadczenie in vitro: niepłodność $i$ nowe technologie reprodukcyjne w perspektywie antropologicznej. Warsaw: Wydawnictwo Uniwersytetu Warszawskiego.

Ratislavova, Kateřina and Jakub Ratislav. 2014. "Asynchronous email interview as a qualitative research method in the humanities." Human Affairs 24:452-460.

Rawal, N. and N. Haddad. 2005. "Use of internet in infertility patients." The Internet Journal of Gynecology and Obstetrics 5(2):1-5.

Sandelowski, Margarete, Diane Holditch-Davis, and Betty G. Harris. 1990. "Living the life: explanations of infertility." Sociology of Health E Illness 12(2):195-215.

Sikorska, Małgorzata. 2016. "'Prywatne' i 'publiczne' konteksty macierzyństwa oraz rozrodczości - analiza dyskursu publicznego." Societas/Communitas 21:137-156.

Skrzypek, Michał. 2011. Perspektywa chorego w socjologii choroby przewlekłej. Lublin: Wydawnictwo Katolickiego Uniwersytetu Lubelskiego.

Slany, Krystyna and Izabela Szczepaniak-Wiecha. 2003. “Bezdzietność - czy nowa wartość we współczesnym świecie." Pp. 159-169 in Systemy wartości a procesy demograficzne, edited by K. Slany and I. Szczepaniak-Wiecha. Cracow: Zakład Wydawniczy NOMOS. 
Sokołowska, Magdalena. 1986. Socjologia medycyny. Warsaw: Państwowy Zakład Wydawnictw Lekarskich.

Talarczyk, Joanna et al. 2012. “Internet jako źródło informacji o niepłodności wśród niepłodnych pacjentek.” Ginekologia Polska 83:250-264.

Tomaszewska, Joanna. 2017. “'Childfree?': praktyki dyskursywne osób bezdzietnych z wyboru w Polsce." Tematy z Szewskiej 2(19):67-84. van Balen, Frank and Marcia Inhorn. 2002. “Interpreting Infertility: A View for The Social Science." Pp. 3-32 in Infertility around the globe: new thinking on childlessness, gender, and reproductive technologies, edited by M. Inhorn and F. van Balen. Berkeley, Los Angeles, London: University of California Press.

Weissman, Ariel et al. 2000. "Use of the Internet by infertile couples." Fertility and Sterility 73(6):1179-1182.

\title{
Citation
}

Walentynowicz-Moryl, Katarzyna. 2020. "In Front of the Mirror of Social Expectations: Experiences of Women Until They Are Given a Diagnosis of Infertility." Przeglad Socjologii Jakościowej 16(1):66-83. Retrieved Month, Year (www.przegladsocjologiijakosciowej.org). DOI: http://dx.doi.org/10.18778/1733-8069.16.1.05

\section{Przed lustrem społecznych oczekiwań - doświadczenia kobiet do momentu otrzymania diagnozy niepłodności}

\begin{abstract}
Abstrakt: Celem artykułu jest przyjrzenie się doświadczeniom kobiet związanym z oczekiwaniami społecznymi dotyczącymi posiadania dzieci. Oczekiwania te wyrażane są poprzez pytania o plany prokreacyjne. Dzięki potraktowaniu doświadczenia prokreacyjnego jako procesu w artykule zrekonstruowano zmiany znaczenia, jakie badane kobiety przypisywały tego typu pytaniom na różnych jego etapach: od etapu przed rozpoczęciem starań o dziecko, poprzez etap początkowy starań o dziecko, etap diagnostyczny, aż do uzyskania diagnozy niepłodności. Kobiety, stojąc przed lustrem społecznych oczekiwań na etapie przed rozpoczęciem przez nie starań o dziecko, widziały w nim swoją przyszłość - siebie w roli matki. Na etapie początkowym starań o dziecko badane dostrzegały w nim swoją bardzo niedaleką przyszłość - siebie w roli kobiety ciężarnej. Na etapie diagnostycznym, aż do uzyskania diagnozy niepłodności, stojąc przed lustrem społecznych oczekiwań, kobiety widziały już tylko swoją niepewną przyszłość - siebie, która bardzo chce, ale nie jest już pewna, czy uda jej się zostać matką.
\end{abstract}

Słowa kluczowe: niepłodność pierwotna, oczekiwania społeczne, macierzyństwo 